\title{
Training mode building of critical thinking ability in college English teaching
}

\author{
Shi-Ping sun ${ }^{1}$ \\ ${ }^{1}$ Chengdu Polytechnic, China
}

Keywords: College English; English teaching; Critical thinking ability; Training mode; Building.

\begin{abstract}
At present, talent competition is increasingly fierce, more and more domestic universities realize the importance of critical thinking ability training in college English teaching, however, it can be seen from the analysis of current teaching situation that the training effect is not ideal. Traditional exam-oriented education thought has a deep effect, many teachers pay more attention to teaching English knowledge, students generally fall into rote learning habits, critical thinking ability training is neglected, the college English teaching reform is imperative. Therefore, this article researches on training mode of critical thinking ability in English teaching, first simply elaborates critical thinking ability, and then analyzes the current English teaching status of critical thinking in colleges, and points out the differences, finally discusses how to construct the training mode of critical thinking ability in college English teaching, in order to further promote the reform of college English teaching.).
\end{abstract}

\section{Introduction}

College English is an indispensable communication tool for college students to move towards society and international community [1]. English is not strange for each college student, they learn English from primary school to senior high school, but they receive exam oriented education for a long time, teachers usually only teach them rigid English theory knowledge, English words, sentences and grammar, when they teach writing, they just take out a simple model essay and let students to imitate, and then ask students to recite the model essay and use it in the exam directly, thus ignoring the students' critical thinking ability in many cases. Now college English teaching has gone through numerous reforms, in new era, more schools have recognized the importance of critical thinking ability cultivation.

\section{Overview of critical thinking ability}

The concept of critical thinking ability has been proposed in very early time, which moved back to Dewey's reflective thinking ability, and developed on Socrates's thinking of reflection and questioning [2]. Socrates clearly pointed out that the answer to the question must have appropriate depth and viewpoint of identifying the fact[3]. Reflective thinking ability mainly refers to the individual's deep thinking ability to a certain assumption or point of view, often considered to be that the individual determines to believe the rationality of something or to do something [4]. In 1980s, many experts and scholars studied together for some time, they launched an objective, rational thinking and self calibration judgment. They did not come to an agreement in the specific concept of critical thinking ability, but we can see that there are common characters in these definitions, which reflect in thinking skills, methods and attitudes. Critical thinking ability is an important ability of reflection, using various skills to judge affairs. In cultivating the ability of critical thinking, teachers can set out from two aspects of cognition and spirit, at the same time, also should further improve the theory teaching of critical thinking ability, and thus enhancing theoretical attainment. 


\section{Current situation of college English's critical thinking teaching}

At this stage, China's higher education reform deepens further and further, the development of college English teaching has made some achievements, but it can not be denied that some of the problems are still not resolved. The main problem is that students are generally lack of interest in learning English, and learning attitude is negative. According to the survey data, more than $40 \%$ of the students are lack of enthusiasm for learning English in the major colleges and universities. The reason is that there is deviation in college English teaching objectives, and the contents of college English are repeated. In addition, in the process of teaching, traditional teaching method is not conducive to explore the students' critical thinking ability, can not improve students' cognitive ability and emotion. In a long period, college English teaching has neglected the cultivation of critical thinking ability, teaching objectives to improve students' language skills, so that students can better respond to various English proficiency tests. In the process of positioning teaching objectives, critical thinking theory is not understood accurately, and also no awareness of its importance, especially the teaching administrative department mainly takes CET-4 \& CET-6 as an important performance appraisal index of foreign language teaching. In this case in order to complete this goal and pursue better performance more teachers take the exam oriented education, and carry on spoon-feeding teaching in class. For students themselves, good grades in CET-4 \& CET-6 mean the English learning works. In essence, the cognition is wrong. On college English curriculum and corresponding teaching mode, the curriculum is relatively single at this stage, many schools only offer major courses of college English, almost without elective courses. The reasons for this situation are, first, compulsory courses have much more credits, but less of elective courses in many colleges and universities; secondly, schools do not have enough teachers, seriously restricting college English teaching, students' thinking ability can not be well trained. Therefore, the teachers pay more attention to language skills learning, such as grammar and vocabulary learning, but training of critical thinking ability is not. This leads to the end of English learning, even get very good marks, the students are lack of language communication ability, simply can not communicate fluently in English with the outside world, in the process of actual communication they cannot analyze and think effectively, and a serious shortage of language organization accuracy and logic.

\section{Training mode building of critical thinking ability in college English teaching}

Table 1 Model of critical thinking ability

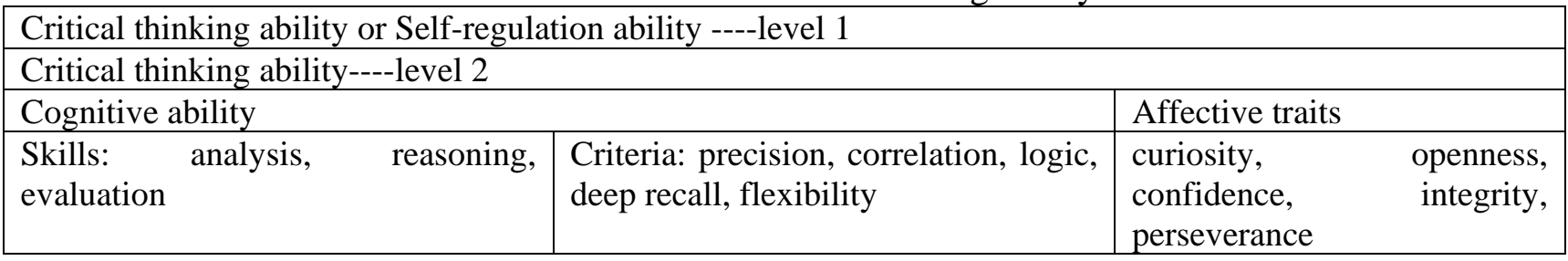

By table 1, it is known that the students' cognitive dimension has three core skills of analysis, reasoning and evaluation, which should be given full consideration in the process of building training mode of critical thinking ability in college English teaching.

\section{A. Guide students to actively question and ask questions.}

Critical thinking ability can be well expressed by emotional quality. In actual teaching, students put forward their own doubts or puzzled to the teachers in the course, which is considered to challenge teachers' authority in many cases, affecting the enthusiasm and initiative of students' query, if things go on like this, the students can only listen, accept and understand passively in class. Lack of enough thinking and analysis for English learning for a long time, students lose their self-confidence gradually, and query ability also degenerate gradually. On the cultivation of critical thinking ability, teachers must work hard to stimulate students to germinate more ideas. It is the most important that the teacher must completely reverse their outdated teacher concept, and adjust their "authority" role 
in class, interact actively with the students, strengthening teaching exchanges, creating a very relaxed and harmonious teaching atmosphere. Easy and pleasant teaching environment has a great positive effect on the students' imagination and urges the students to analyze and judge more positively, which can make the students' English learning more effective. In addition, it is not necessary for the interior layout of classroom in accordance with the original pattern, the seat arrangement can be adjusted completely in combination with the actual needs of class teaching, making the layout more flexible, the classroom can be equipped with some free moving chairs, which is convenient for students to carry out various activities in classroom, and strengthen students' mutual exchanges and communication between teachers and students. In the actual teaching activities, teachers should actively guide and encourage students to express their views more bravely, at the same time, evaluate students' performance correctly and reasonably at the first time in class, giving students a sense of accomplishment and self-confidence, and further expanding students' critical thinking space.

\section{B. Reasonable learning of knowledge and language.}

Combined with the theory of critical thinking levels, as one of the human skills, critical thinking ability can be improved a lot by practicing and training. In the actual teaching course students accept the corresponding training, and gradually improve their critical thinking ability, that is, self-regulation ability. Teachers can check students' critical thinking ability in real time, and timely adjust and correctly evaluate, which could prompt the students to better play their initiative and leading role, at last according to the promotion of cognitive skills and characteristics of emotional training and other activities, students' cognitive ability could be obviously improved. There are two main types of critical thinking teaching's form, one is independent course, the other is content-based course. The former mainly refers to critical thinking training course, students can choose these courses to have professional thinking training in the process of learning English. Content-based course is mainly determined by the specific teaching methods, the purpose for students learning a foreign language is to gain more knowledge and learn things they want to know, at the same time, students can draw support from academic knowledge, significantly promoting their language and critical thinking ability. In United States and some developed countries, not only critical thinking ability course is set as a special course to train logical thinking targetedly, but also other abilities are being strengthened in the courses. Launching critical thinking ability training classes is consistent with the requirements of critical thinking system training, but with strict requirements for teachers, which not only needs a sufficient number of teachers, also the teachers should be highly qualified. Teachers should not only have professional accomplishment, but also have a mass of teaching resources, but currently a serious shortage of teachers in the professional courses in most domestic colleges and universities, and the professional quality of teachers needs to be further enhanced. In this case, colleges and universities must strive to increase the investments for teachers, and effectively improve the professional quality of teachers from the overall. In contrast, the development of critical thinking teaching content is decided by the teaching types to a great extent, teachers need to connect the teaching content actually, take subject knowledge theory as the carrier, and use a series of teaching of critical thinking content to promote students' independent analyzing ability, so that the students can better handle the current problems. Thus critical thinking teaching can strengthen and promote students' critical thinking ability, and promote the realization of teaching objectives of college English effectively.

\section{Strengthen personalized learning.}

In the process of teaching, teachers can guide students to learn independently, thus improving their abilities of analysis, reasoning and evaluation significantly. Students can continuously adjust, manage and optimize their cognitive process, plan the future reasonably, as the same time make self management, monitoring and evaluation, etc. Autonomous learning is an effective way to enhance students' self cognition and critical thinking ability, and can also improve the students' emotion. In the process of autonomous learning, we must pay close attention to two key points: first, effectively stimulate the enthusiasm of students and mobilize the learning motivation, so that students can learn more independently. Second, create an independent learning environment, and build a good network learning platform by modern educational technology. From this, the students can obtain more 
abundant teaching resources, which can be easier for students to grasp more effective critical thinking ways. Autonomous learning is not single and fixed, students can choose the right way according to the teacher's guidance. For example, under the guidance of teachers, a student read a story and he can adapt the story according to his imagination, which will enhance his language and critical thinking ability. In addition, the form of team cooperation can also be taken. By team cooperation students can get more information conveniently, on the other hand, the students can get greater emotional support, and learn to listen to others' suggestions and opinions, which can prompt students to master more ideas and ways of thinking, thus promoting his ability for solving problems. The active learning of students is a strong support to enhance the ability of critical thinking, autonomous learning can significantly motivate students' initiative, make them think independently, and ultimately they will have rational and correct judgment.

\section{Conclusion}

In conclusion, previous college English teaching is generally lack of the cultivation of critical thinking ability, which causes the student can not well adapt to the social development and can not meet the needs of modern enterprises' development, thus the teachers must strive to enhance students' critical thinking ability. According to the discussion above, the status of critical thinking ability promotion in college English teaching is not ideal at this stage, we can actively construct corresponding training mode of critical thinking ability, promote students' critical thinking ability, and improve the status of English teaching.

\section{References}

[1]Liu Xiaomin. Discussion on cultivation mode building of critical thinking ability in college English teaching[J]. Foreign language world, 2013,05:59-66.

[2]Yu Xin. Cultivation mode building of critical thinking ability in college English teaching [J]. Shandong Social Sciences, culture 2015, S2:347-348.

[3]Dan Jin. Analysis of cultivation mode building of critical thinking ability in college English teaching [J]. English Square, 2016,03:123-124.

[4]Wang Xuemei. Analysis of cultivation mode building of critical thinking ability in college English teaching [J]. Overseas English, 2015,22:103-104.

[5] Li Lijun. A brief analysis of cultivation mode building of critical thinking ability in college English teaching[J]. The Guide of Science \& Education (late), 2016,04:116-117.

[6] Zhang Hao. Discussion on cultivation mode building of critical thinking ability in college English teaching[J]. Journal of Heilongjiang Institute of education, 2015,05:147-148. 